\title{
Knowledge, Attitude, and Practices (KAP) about Sexual Harassment at Workplace: A Roadmap for Sustainable Workplaces
}

\author{
By Upma Gautam ${ }^{1}$, Deeksha Bajpai Tewari ${ }^{2}$
}

\begin{abstract}
Globalization, its corollaries -increased female literacy levels and rapid urbanization, has brought a radical change in women worldwide. However, with the more significant influx of women in India's mainstream workforce, sexual harassment at the workplace has assumed more critical dimensions. Assessment of the awareness, attitudes, and perception of colleagues towards the victim, victimization, and the wrongdoer through a KAP research methodology which is meant to be a representative survey of a target population, forms the central focus of the study. The sample size was 512 respondents from public and private sector undertakings. The structured questionnaire consisted of four core sections ranging from including respondent's socio-demographic characteristics to including questions regarding the assessment of respondents' knowledge of sexual harassment at the workplace and committee to address the issue, their attitudes towards sexual harassment at the workplace, and inquiries about practice towards sexual harassment at workplace. The study affirms, firstly, both public and private sector organizations lack in their rehabilitative approach towards the victim. Secondly, the co-workers' approach both in the private and public sector lacks sensitivity and includes victimblaming. Thirdly, there is a need for sensitization training of ICC members. Building Safe workplaces is a prerequisite to building sustainable workplaces.
\end{abstract}

Keywords: Sexual harassment at workplace, KAP, Sustainable workplaces, gender equality, women workforce participation

\section{Introduction}

Women's rights and issues have always been a subject of serious concern of academicians, intelligentsia, and policy makers. From pastoral society to contemporary information and global society, the role of women has changed drastically. The continuity of changes in socio-economic and psycho-cultural aspects of human living has influenced the role of women. With the process of industrialization, modernization and globalization showing its deep impact on the human society all over the world, the role and responsibilities of women has attained new definition and perspective. On the encouraging front, in the South Asian Countries there have been relatively increasing economic participation in past one decade. Statistically, the rate of literacy among women has also increased. The educational and occupational patterns have also changed and widened with women entering the domains, which till decade was dominated by men. In the background of the gigantic transformation, the core issue, which remains unanswered, is that of

$\mid{ }^{1}$ Assistant Professor, University School of Law and Legal Studies, Guru Gobind Singh Indraprastha University, Delhi, India

${ }^{2}$ Assistant Professor, Department of Geography, Dyal Singh College, University of Delhi, India; Corresponding Author 
women's right and empowerment. Long bygone are the days when men used to be the sole breadwinners of a family. Globalization has brought a radical change in the status of women worldwide. However, with the larger influx of women in the mainstream workforce of India, sexual harassment at workplace has assumed greater dimensions. Workplace sexual harassment is a form of gender discrimination which violates a woman's fundamental right to equality and right to life, guaranteed under Articles 14, 15 and 21 of the Constitution of India ("Constitution").

Harassment in its essence is unwarranted conduct having its basis in either gender, sex, religion, color, disability, or nationality. However, discriminatory practices leading to harassment can have many other bases as well. In contemporary times gender-based (in) equalities at the workplace are crucial concerns addressed globally by academia, legal practitioners, policymakers, and civil society members.

Universally, Sexual Harassment at the workplace in its varied forms of hostility against any gender is a complex social issue. The relationship between an employer and employee, a teacher and a student, a commanding officer and his subordinate army officer, an attorney, and his intern are power centric(M. Reena, 2014). In contrast with other forms of sexual assaults, which are more about sexual gratification(Barbara A. Gutek \& Morasch, 1982), sexual Harassment at Workplace is more about male dominance(Gruber, 1992), powerplay(McLaughlin et al., 2012). It is contended to be a gross human right violation and denial of the right to a dignified life. Male dominance plays a vital role in women's subdued position wherein women in disadvantageous positions are discriminated against on account of their deviance from traditionally decided gendered roles for her(Coles, 1986; Settles et al., 2014; Wilson \& Thompson, 2001).

Further, the impact of sexual harassment on women is multifold, which cannot be quantified since the injury per se is not visible though grave in nature. Against the patriarchal cultural backdrop, the wide range of bearings for women includes shame, embarrassment, guilt, frustration, absenteeism, lower productivity, humiliation, hopelessness, and finally breaking down emotionally(Gallus, 2010; Glomb et al., 1997; Pryor et al., 1995; Settles et al., 2014). Economic dependency, vulnerability, and lesser career choices offered by the market in the name of "suitability" and "security" add to quantum the wrong.

When defining "sexual harassment," the term is defined by the scholars from varied perspectives. For instance, it is defined and analyzed from the gender relation perspective(Bridges \& Messerschmidt, 2019; Stockdale et al., 1995; Stockdale \& Vaux, 1993). At the same time, the legal provisions, and international instruments focus on the question as to what behaviors and actions can be included within the scope of Sexual Harassment at the workplace. Taking the concept of sexually "colored" Harassment at Workplace or work-related premises, the scholars have extended the understanding of this wrong as the indicator of unequal social status between man and woman rather than only a manifestation of biological differences amongst them.

Sexual Harassment at Workplace not only leaves back a distressed target but also undercuts the fundamental tenets of dignity, mutual respect, and human considerations. Even though this wrong results in the highest degree of discrimination and consequential losses, mental, physical, and financial, at the workplace, for a significant period, it was perceived as "personal," which was not even discussed in legal contours. In pursuance of commandments in international conventions, today, it is unambiguously acknowledged, 
accepted, and incorporated as a penal wrong in almost all legal systems.

\section{Materials and Methods}

This is an empirical field- oriented research. Structured questionnaire based on the objectives of the study were prepared with the aim to identify the gendered responses to sexual harassment (Barling et al., 1996), structure and working of ICC in different organizations of public and private sector, as well as about organizational approach towards such incidents. The questionnaire was circulated amongst the population of diverse work profiles to accommodate representation of different organizations both from the private and public sector. As a preliminary step, the stakeholder groups in this study identified includes employees or owners of enterprises from private sector, employees from the public sector including Government and the public sector undertakings, category of employees termed as 'others' will include non-governmental organizations, freelance workers. It will be ensured that respondents belong to a vast gamut of organizations including Governmental hospitals, private firms, University departments, aviation etc. This questionnaire was circulated both through digital format as well as in physical form. The questionnaire aimed to identify the incidents of sexual harassment at workplace identified as - firstly, Quid Pro Quo (literally meaning 'this for that') and secondly, hostile Work Environment.

Based on the scope and objective of research, this study primarily focusses on the qualitative approach and to support the arguments and understand the trends in number of cases of sexual harassment reported, secondary statistical data is used.

The sample size of the present study was 512 respondents. Structured questionnaire was prepared. The sample was purposively selected to accommodate representation of different organizations both from the private and public sector. Certain important questions in questionnaire pertained to the gendered responses about sexual harassment (Barling et al., 1996), structure and working of ICC in different organizations of public and private sector, as well as about organizational approach towards such incidents.

\subsection{Questionnaire}

The questions in the Questionnaire were generated based on the results of literature reviews of earlier studies about Sexual harassment at workplace. The Questionnaire consisted of four core sections. The first section referred to the respondents' socio-demographic characteristics, including age, gender, marital status, work status. The second section included questions regarding the assessment of respondents' knowledge of sexual harassment at workplace and availability of a committee to address the issue. This section had 09 questions. The third section assessed participants' attitudes towards sexual harassment at workplace. A five-point Likert scale was used. For each of the statements in this section, the respondents were asked to mark their agreement level ranging from "strongly disagree" to "strongly agree." Regarding inquiries related to practice towards sexual harassment at workplace, only two options of "yes" and "no" were assigned. The Questionnaire was re-validated using the Rasch model measurement. It showed that the Questionnaire had acceptable reliability and validity, with Real item reliability (Real RMSE) 0.98 for attitude scale, 0.98 for knowledge scale, and 0.99 for practice scale. 


\section{Gendered Workspaces with Gendered Social Constructs: Typology of Sexual Harassment at Workplace}

Sexual Harassment at Workplace has social connotations attached. It cannot be understood in a vacuum without investigating the social realities and different social constructs impacting the said "wrong" in any society. In any social setup, while dissecting the Harassment at Workplace which is sexually colored, it is to be understood that firstly, that though at the very outset though it is discriminatory, such depicted behavior is not correlated with that of qualification or job performance of the concerned employee. Secondly, how society members react to this "wrong" is primarily based on the perceptions about the sexuality of male and female members and about their designated roles socially, economically, and politically(Haspels et al., 2001).

Sexual Harassment at Workplace as a concept witnessed the remarkable transformation from being considered merely a "problem" faced by women until it is recognized as a legal wrong. It is regarded as an explicit form of gendered violence in U.N. Declaration on the Elimination of Violence against Women(1993), thereby impacting the physical, mental, and sexual health of the women when compared with rape and other sexual assaults is contended to share the commonality of expression of "exercise of power" by one over the other(Barbara A. Gutek et al., 1983; Jensen \& Gutek, 1982; Sheffey \& TINDALE, 1992). Researchers have developed three major theories in their work while attempting to explain sexual harassment, namely, the Theory of male dominance, gender- role spillover, and sex ratio theory, thereby suggesting that relative powerlessness, stemming from both- job insecurity and social acceptance of the role of women as subordinate to men coupled with lower standing of the women in the hierarchy at the workplace is a significant determinant of victimization and a prime cause of a variety of Harassment at Workplace including sexual harassment(Back, 1965; Baron, 1987; Lovell \& Jacoby, 1987)

Unlike rape, where social dominance and superior positioning in the ladder are shown by the usage of physical power while committing the offense, sexual Harassment at Workplace the same is done by using the organizational superiority in the backdrop of being socially conditioned as superior gender. It has been argued that male colleagues to maintain their dominance, privilege, and power reduce female colleagues to objects of "sex" by sexually colored behavior.

Reporting, redressal, and perception of "tolerance": The policies and provided procedure for handling sexual harassment complaints, in addition to past actions taken against the harasser in the organization(Mask, 1997; T., 2020), plays a significant role in the reporting of cases. As it is often contended that the perception of the organization as "tolerant" to harassment(Buchanan et al., 2013) or in favor of a sexualized work environment(B. A. Gutek \& Koss, 1993) caused due to "glaring omissions"(Mohd Nazari Ismail, 2007; Wasti et al., 2000) often results in increased incidents of harassment at the workplace underreporting(Cochran et al., 1997). Further, the generalized perception about the internal complaint committee dealing with complaints and the victim's expectation about the committee's efficiency are critical deciding factors for seeking assistance from within the organization or outside the workspace.

It is further contended based on the conducted studies that a large section of quid pro quo types of sexual harassment incidents is reported to the victims' authorities. Still, most other 
types of sexual harassment are not registered for myriad reasons varying from nonavailable grievance redressal mechanism to shame and despair, which often lasts long even after the harassment has ended(Lopez et al., 2016). Further studies substantiate the wide range of reasons behind the reluctance for reporting to take formal actions. Apart from the reasons mentioned above, lack of faith in the organization's anti-sexual harassment machinery tops the chart. Underreporting is stated to be fear that no formal action will be taken against the wrongdoer, further adding to the complainant's embarrassment.

The dynamics of sexual harassment become much more complicated when allegations are made by the not (so) powerful party, and consensual sex, which was not (so) consented, makes things much worse. In such situations, it becomes enormously difficult to conceptualize consent, victimization, and the very concept of "victim," which is judged from a lens of various social constructs and myths attached to such harassment. Due to these myths and stereotyped perceptions about the "victim" and "victimization" in public spaces, the reporting of sexual harassment by a superior is under- reported.

\section{Knowledge, Attitudes and Practices (KAP) study of Sexual Harassment at Workplace: Public and Private Sector}

KAP surveys originated in the 1950s in the fields of family planning and population research. These are also known as knowledge, attitude, behavior, and practice surveys. These are now widely accepted for the investigation of health-related behaviors and health-seeking practices. A KAP survey is meant to be a representative survey of a target population; it aims to elicit what is known (knowledge), believed (attitude), and done (practiced) in the context of the topic of interest. Information is collected using semi structured or (more usually) structured questionnaires that are self-administered or administered by interviewers; both qualitative and quantitative data may be collected( Lafontaine \& Tredeau, 1986; WHO, 2008).

A Knowledge, Attitude and Practices (KAP) survey is a quantitative method (predefined questions formatted in standardized questionnaires) that provides access to quantitative and qualitative information. KAP surveys reveal misconceptions, misunderstandings, knowledge levels of the respondents that have a potential to act as obstacles to the activities that we would like to implement (in the current case safe workplace) and potential barriers to behavior change. Note that a KAP survey essentially records an "opinion" and is based on the "declarative" (i.e., statements). In other words, the KAP survey reveals what was said, but there may be considerable gaps between what is said and what is done. For the current study, a KAP study was designed to understand the knowledge, attitude, and practices of the stakeholders, i.e., people employed in different organizations - public and private undertakings about sexual harassment at workplace, individuals involved in these acts, their positions in the organizations, methods of grievance redressal available to the survivor, etc. A total of 604 persons responded to the survey. Out of these, a total of 512 responses became part of the study. 92 responses were excluded due to incomplete survey. 
Table 1: Socio-Demographic Profile

\begin{tabular}{|l|c|c|}
\hline Variables & $\mathbf{N}=512$ & Percentage (\%) \\
\hline Gender & & \\
\hline Male & 254 & 49.6 \\
\hline Female & 258 & 50.4 \\
\hline Age Category (years) & & \\
\hline $18-29$ & 208 & 40.71 \\
\hline $30-39$ & 86 & 16.76 \\
\hline $40-49$ & 101 & 19.76 \\
\hline $50-59$ & 66 & 12.87 \\
\hline $60 \&$ above & 51 & 9.88 \\
\hline Marital Status & & 70.95 \\
\hline Married & 363 & 26.94 \\
\hline Not Married & 138 & 2.09 \\
\hline Others & 11 & \\
\hline
\end{tabular}

Out of the total respondents, 254 (49.6 percent) were men and 258 (50.4 percent) were women. Nearly 41 percent of the respondents were in the age group of 18-29 years. About 71 percent respondents were married. Other demographic characteristics are detailed in Table 1.

Table 2: Type and Duration of Employment

\begin{tabular}{|l|c|c|}
\hline Variables & N=512 & Percentage (\%) \\
\hline Employment & & 33.0 \\
\hline Government & 169 & 47.46 \\
\hline Private & 243 & 18.75 \\
\hline PSU & 96 & 0.78 \\
\hline Others & 4 & \\
\hline & & \\
\hline Years of Work Experience & & \\
\hline & 10.41 years & \\
\hline
\end{tabular}

As is evident from Table 2, about 47 percent of the respondents were employed in the private sector organizations. 51.75 percent respondents belonged to government sector including public sector undertakings. Average years of employment for the respondents were 10.41 years. Many respondents had at least a decade of work experience.

\subsection{Assessment of Knowledge}

The study used nine questions to measure the respondents' knowledge about events of sexual harassment at workplace. The responses were recorded as 'yes', 'no' and 'I don't know'. The questions were framed to understand if the respondents are aware of the events of sexual harassment at workplace, then firstly, whether they have information of the professional hierarchical relationship shared by the harassed and the harasser. Secondly, the category in which they put the harassment, including, physical contact and advances, demand, or request for sexual favors, sexually colored remarks, display of pornography etc. Thirdly, respondents' knowledge about reporting of such events was also 
assessed. Fourthly, whether the respondents' have any knowledge about any committee in the organization to address such complaints was also assessed. Lastly, the respondents were also asked whether they had any knowledge about any Court guidelines, Act or legal provisions existing for addressing such complaints.

Table 3: Respondents: Knowledge about the event of Sexual Harassment at the Workplace

\begin{tabular}{|c|c|c|c|c|c|}
\hline Respondents & & $\begin{array}{l}\text { Have knowledge } \\
\text { about event of } \\
\text { sexual } \\
\text { harassment at } \\
\text { their workplace }\end{array}$ & $\begin{array}{c}\text { Percentage of } \\
\text { respondents with } \\
\text { knowledge about } \\
\text { event of sexual } \\
\text { harassment at their } \\
\text { workplace }\end{array}$ & $\begin{array}{c}\text { Do not have } \\
\text { knowledge about } \\
\text { event of sexual } \\
\text { harassment at } \\
\text { their workplace }\end{array}$ & $\begin{array}{l}\text { Percentage of } \\
\text { respondents without } \\
\text { knowledge about } \\
\text { event of sexual } \\
\text { harassment at their } \\
\text { workplace }\end{array}$ \\
\hline Male & 254 & 129 & 50.78 & 125 & 49.21 \\
\hline \multicolumn{6}{|l|}{ Employment } \\
\hline Government & 82 & 42 & 51.21 & 40 & 48.75 \\
\hline Private & 111 & 56 & 50.45 & 55 & 49.54 \\
\hline PSU & 59 & 31 & 52.54 & 28 & 47.45 \\
\hline Others & 02 & 0 & 0 & 2 & 100 \\
\hline Female & 258 & 139 & 53.87 & 119 & 46.12 \\
\hline \multicolumn{6}{|l|}{ Employment } \\
\hline Government & 77 & 40 & 51.94 & 37 & 48.05 \\
\hline Private & 134 & 75 & 55.97 & 59 & 44.02 \\
\hline PSU & 39 & 20 & 51.28 & 19 & 48.71 \\
\hline Others & 8 & 04 & 50.0 & 4 & 50.0 \\
\hline Total & 512 & 268 & 52.34 & 244 & 47.65 \\
\hline
\end{tabular}

The spectrum of employment of male and female respondents were as follows: Out of total 254 male respondents, 141 (about 56 percent) belonged to the government sector including public sector unertakings.111 (about 44 percent) worked in private sector organizations. Out of a total 258 female respondents, 116 (45 percent) worked in government sector and 134 (about 52 percent) worked in the private sector undertakings.

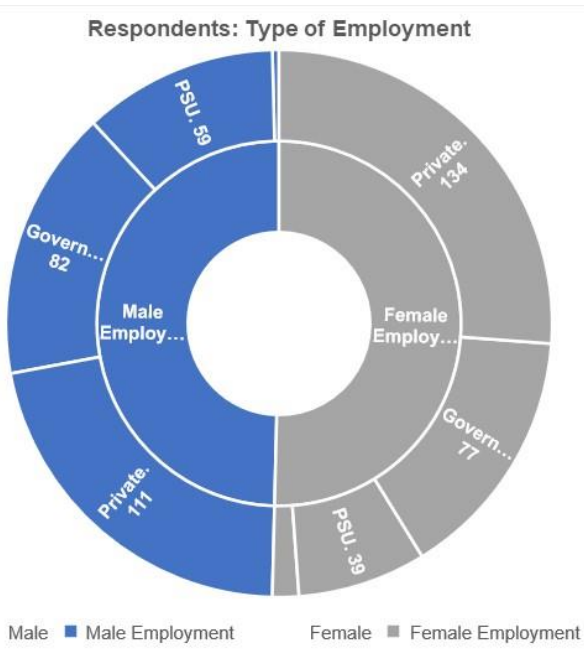


Out of the total 512 respondents, about 52 percent respondents (nearly 54 percent female, 51 percent male) had knowledge about events of sexual harassment at their workplaces. Remaining about 48 percent (about 46 percent female, 49 percent male) did not have such knowledge. Among the male respondents, those working in PSUs, followed by those in the government sector were aware of events of sexual harassment at their workplaces. On the contrary, among the female respondents, those working in the private sector undertakings were most aware of events of sexual harassment in their workplaces. On a very generic level, a high proportion of respondents' having no knowledge about events of sexual harassment may also be explained by the non-reporting of such events in different organizations.

Professional Relationship between the Harassed and the Harasser

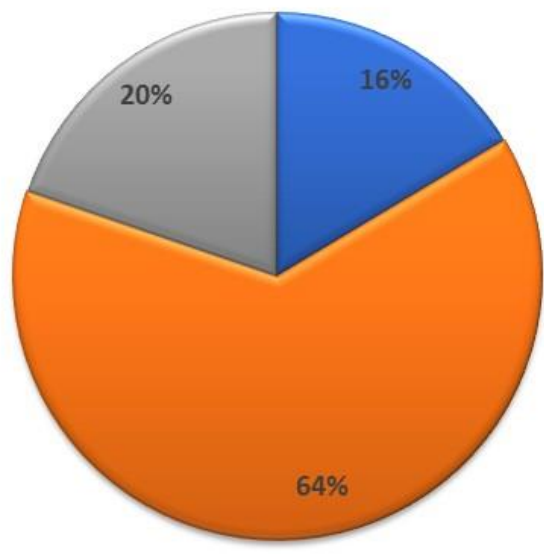

- Co-Workers $\square$ Subordinate reporting to a Senior $\square$ Subordinate not reporting to Senior

About 64 percent of the respondents had knowledge about events of sexual harassment at their workplace between seniors and their reporting subordinates. Thus, the premise that sexual harassment at workplace is reflective of hierarchical power equations in the workplace. It is contended that in traditional occupations sexual harassment at workplace is quite often derived by male dominance(Gallus, 2010; Gruber, 1998) and power play(Wilson \& Thompson, 2001) than fulfillment of sexual desire(Coles, 1986). It has been argued that male colleagues to maintain their dominance, privilege and power reduce female colleagues to objects of "sex" by such sexually colored behavior.

Overwhelming majority (about 84 percent) of the respondents had knowledge of sexual harassment between a subordinate and a superior she reports to or a senior that the harassed does not report to but nonetheless is in a higher power centric position in the organization. 


\begin{tabular}{|l|l|l|l|l|l|}
\hline \multicolumn{1}{|c|}{ Male and Female Respondents: Relationship between the Harasser and the } \\
Harassed
\end{tabular}

Male respondents in the government sector showed higher knowledge of sexual harassment between the senior and a subordinate as compared to female respondents in the government sector. But female respondents in the private sector organizations and in the PSUs had a higher knowledge about events of sexual harassment between a senior and a subordinate. When compared with sexual harassment between co-workers, it is evident that the power structures of the organizations and in the society provide the bulwark and lubricant for events of sexual harassment at workplace.

About 35 percent respondents had knowledge that physical contact and advances were the methods of harassment, 26 percent stated that demands for sexual favors were made and 22 percent stated that sexually colored remarks were made to harass the female colleagues. About 62 percent of the respondents had knowledge about the reporting of such events of sexual harassment at workplace. Remaining had no such knowledge. About 62 percent of the total respondents had knowledge of a committee at their workplace to address such complaints. About 82 percent of the total respondents had knowledge about an Act and a legal provision to address events of sexual harassment at workplaces.

\subsection{Assessment of Attitude}

The third section assessed participants' attitudes towards sexual harassment at workplace. A five-point Likert scale was used. For each of the statements in this section, the respondents were asked to mark their agreement level ranging from "strongly disagree" to "strongly agree." The items reflect attitudes regarding the perceived utility, importance, and benefits of reporting (e.g., "Reporting workplace sexual harassment is an effective way of stopping the problem") as well as the perceived drawbacks (e.g., "People who report workplace sexual harassment usually end up getting into trouble for it"). Response options 
ranged from 1 (strongly disagree) to 5 (strongly agree). Six questions on assessing the attitude of the respondents were used.

Table 4: Responses to Attitudinal Responses about Sexual Harassment at Workplace

\begin{tabular}{|l|c|c|c|c|c|}
\hline & $\begin{array}{l}\text { Strongly } \\
\text { disagree }\end{array}$ & Disagree & Neutral & Agree & $\begin{array}{l}\text { Strongly } \\
\text { agree }\end{array}$ \\
\hline $\begin{array}{l}\text { If someone is being sexually harassed in his or } \\
\text { her place of work, then s/he should report it to a } \\
\text { supervisor }\end{array}$ & $9(1.75)$ & $18(3.51)$ & $25(4.88)$ & $345(67.38)$ & $115(22.46)$ \\
\hline $\begin{array}{l}\text { Reporting workplace sexual harassment is an } \\
\text { effective way of stopping the problem }\end{array}$ & $83(16.21)$ & $125(24.41)$ & $100(19.53)$ & $145(28.32)$ & $59(11.52)$ \\
\hline $\begin{array}{l}\text { A person who reports workplace sexual } \\
\text { harassment is just a tattletale }\end{array}$ & $134(26.17)$ & $169(33.00)$ & $85(16.60)$ & $82(16.01)$ & $42(8.20)$ \\
\hline $\begin{array}{l}\text { Reporting workplace sexual harassment creates } \\
\text { new problems for everyone }\end{array}$ & $121(23.63)$ & $150(29.29)$ & $28(5.46)$ & $127(24.80)$ & $86(16.79)$ \\
\hline $\begin{array}{l}\text { People should not be afraid to report sexual } \\
\text { harassment in their workplace }\end{array}$ & $22(4.29)$ & $48(9.37)$ & $62(12.10)$ & $160(31.25)$ & $220(42.96)$ \\
\hline $\begin{array}{l}\text { Workplace sexual harassment problems will } \\
\text { persist, even if people report them }\end{array}$ & $28(5.46)$ & $30(5.85)$ & $12(2.34)$ & $90(17.57)$ & $352(68.75)$ \\
\hline
\end{tabular}

An overwhelming majority (about 89.84 percent) of respondents had a positive outlook regarding reporting of events of sexual harassment at workplace and about 74.21 percent of them responded that the survivor should not be afraid of reporting such events. But, regarding the efficacy of reporting the workplace sexual harassment equal proportion of respondents (about 40 percent) agreed that it is an effective measure of stopping the menace, but qual proportion of respondents also disagreed with the statement. The pessimistic approach of the respondents also showed through while replying to the question that even if reported, sexual harassment at workplace will prevail. It not only points towards the social construction and infallibility of the problem but also raises questions about the working of the Internal committees in addressing such complaints.

\subsection{Assessment of Practices}

In this study, practices towards sexual harassment at workplace were measured through three questions: reporting of sexual harassment at workplace was the sole responsibility of the person being harassed, have they ever deposed in any fact-finding committee, when called and if they ever faced sexual harassment at their workplace will they report it to a senior or supervisor. Every sound practice was marked as "1," and every bad practice was allotted "0".

\section{Table 5: Responses to Practices Responses about Sexual Harassment at Workplace}

\begin{tabular}{|l|c|c|}
\hline $\begin{array}{l}\text { Reporting of sexual harassment at workplace was the sole responsibility of } \\
\text { the person being harassed }\end{array}$ & $482(94.14)$ & $30(5.86)$ \\
\hline $\begin{array}{l}\text { Have they ever deposed in any fact-finding committee, when called } \\
\begin{array}{l}\text { If they ever faced sexual harassment at their workplace, will they report it to a } \\
\text { senior or supervisor }\end{array}\end{array}$ & $29(5.66)$ & $483(94.33)$ \\
\hline
\end{tabular}

About 94 percent of the respondents believed the person being harassed should only 
report the complaint. This does not auger well for the working environment of organizations and points to the lacuna that human resource management wings of the companies need to address. This behavioural practice on the part of co-workers' vis-vis the person harassed will further isolate the victim and can lead to ugly practices like shaming, stereotyping, bullying etc. Also, a large majority of the respondents had never ever deposed in any fact-finding committees constituted for addressing sexual harassment at workplaces. Even though their responses were that they were never called by the committee, when seen I the light of the first question raises doubts about the responses. About 69 percent of the respondents, including men, believed that if they face sexual harassment at their workplace they will report to the higher authorities.

\section{Conclusion: Carving out the Working Relations}

"Attempts to understand women from South Asia must be contextualized through socioeconomic, religious and geopolitical particularities along with an understanding that a legal provision does not mean implementation, and that discrimination persists within the family and societal institutions."

South Asia is a region where the maximum member states are signatories to CEDAW, MDGs, SDGs, and having the legal framework generally in conformity with the international mandate is still struggling with the staunch reality of increased incidents of Sexual Harassment at the workplace. Though the region has witnessed remarkable changes after the watershed movements like protests after the infamous Nirbhaya Rape case in India or Aurat March in Pakistan, and the legislative changes after that has not only empowered women but also helped them to raise their voices to fortify their rights, political, social, or financial.

The legislation in place can be a starting point for redressing the mischief but can never be an end, and sexual Harassment at Workplace is no exception to this rule. In the backdrop of the social realities and attached perceptions around this "wrong," the fact remains the same irrespective of the type of organization. The position women are holding in it that reporting such events of harassment is traumatic. Additionally, the situation attains grave proportions in the absence of a sensitized internal complaint committee. It cannot be denied that the" social stereotyping" of the victim plays a role of that "invisible witness" whose corroborative value is exceptionally high while deciding such cases.

The region where the percentage of work participation of women is comparatively low, like for instance Sri Lanka having 35\%, Bangladesh, Pakistan, and India ranging between $18 \%$ to $26 \%$ of employees(Strachan et al., 2015), a robust and progressive legal framework, and policies along with transparent procedures will lead to not only improved figures but also more productive workforce. For this purpose, the member states in this region must focus on formulating the policies and procedures centered around rehabilitative approaches towards the victim/complainant, thereby promoting the complainant's mental health and well-being may it be in the government or private sector. For the purpose mentioned above, a gender sensitized redressal committee is a pre-requisite for which the committee members must frequent training to decide the complaint more objectively without any preconceived biases.

Further, as the study revealed that the number of women workers working in the private sector is a significant factor in influencing the number of sexual harassments at workplace 
complaints registered, the formal procedures and structures to deal with such complaints like government sector are supposed to be well defined in private sector organizations also. Since the data reveals that very few of the complaints are reported in India to the police after the conclusion of ICC inquiry as the matter is generally compounded between both the parties, it becomes more critical that the procedures within the organization are well defined, transparent, and therapeutic in their approach. Unlike India, there is a lack of data in the public domain regarding sexual harassment complaints in other member states. The research conducted is profession specific. The present study model paves the way for further research to conduct a comparative analysis of sexual harassment complaints. Once the pattern is analyzed on varied factors, an inclusive policy for furthering women's interests can be formulated for the region, which will regulate the inter-entrepreneurial relationships among the member states more effectively.

\section{Acknowledgement}

The study was funded by Faculty Research Grants Scheme, Guru Gobind Singh Indraprastha University, Dwarka, New Delhi.

\section{References}

Back, K. W. (1965). Exchange And Power In Social Life. By Peter M. Blau. New York: John Wiley \& Sons, 1964. 352 pp. \$7.75. Social Forces. https://doi.org/10.2307/2574842

Baron, J. N. (1987). Employing Bureaucracy: Managers, Unions, and the Transformation of Work in American Industry, 1900-1945. Sanford M. Jacoby . American Journal of Sociology. https://doi.org/10.1086/228595

Bridges, T., \& Messerschmidt, J. W. (2019). Joan Acker and the shift from patriarchy to gender. Gender, Work and Organization. https://doi.org/10.1111/gwao.12226

Buchanan, N. C. T., Bluestein, B. M., Nappa, A. C., Woods, K. C., \& Depatie, M. M. (2013). Exploring gender differences in body image, eating pathology, and sexual harassment. Body Image. https://doi.org/10.1016/j.bodyim.2013.03.004

Cochran, C. C., Frazier, P. A., \& Olson, A. M. (1997). Predictors of responses to unwanted sexual attention. Psychology of Women Quarterly. https://doi.org/10.1111/j.1471-6402.1997.tb00109.x

Coles, F. S. (1986). Forced to quit: Sexual harassment complaints and agency response. Sex Roles. https://doi.org/10.1007/BF00287850

Gallus, J. A. (2010). Whistle-blowing following sexual harassment: Examining the intricacies of reporting within a planned behavior framework. In ProQuest Dissertations and Theses.

Glomb, T. M., Richman, W. L., Hulin, C. L., Drasgow, F., Schneider, K. T., \& Fitzgerald, L. F. (1997). Ambient sexual harassment: An integrated model of antecedents and consequences. Organizational Behavior and Human Decision Processes. https://doi.org/10.1006/obhd.1997.2728

Gruber, J. E. (1992). A typology of personal and environmental sexual harassment: Research and policy implications for the 1990s. Sex Roles, 26(11-12), 447-464. https://doi.org/10.1007/BF00289868

Gruber, J. E. (1998). The impact of male work environments and organizational policies on women's experiences of sexual harassment. Gender and Society. https://doi.org/10.1177/0891243298012003004

Gutek, B. A., \& Koss, M. P. (1993). Effects of sexual harassment on women and organizations. In Occupational medicine (Philadelphia, Pa.).

Gutek, Barbara A., \& Morasch, B. (1982). Sex-Ratios, Sex-Role Spillover, and Sexual Harassment of Women at Work. Journal of Social Issues. https://doi.org/10.1111/j.1540-4560.1982.tb01910.x

Gutek, Barbara A., Morasch, B., \& Cohen, A. G. (1983). Interpreting social-sexual behavior in a work setting. Journal of Vocational Behavior. https://doi.org/10.1016/0001-8791(83)90004-0

Haspels, N., Kasim, Z. M., Thomas, C., \& Mccann, D. (2001). Action against Sexual Harassment at Work in Asia and the Pacific (Issue October). http://www.ilo.org/wcmsp5/groups/public/---asia/---robangkok/documents/publication/wcms_bk_pb_159_en.pdf 
Jensen, I. W., \& Gutek, B. A. (1982). Attributions and Assignment of Responsibility in Sexual Harassment. Journal of Social Issues, 38(4), 121-136. https://doi.org/10.1111/j.1540-4560.1982.tb01914.x

Lafontaine, E., \& Tredeau, L. (1986). The frequency, sources, and correlates of sexual harassment among women in traditional male occupations. Sex Roles, 15(7-8), 433-442. https://doi.org/10.1007/BF00287982

Lopez, S. H., Hodson, R., Roscigno, V. J., Lopez, S. H., Hodson, R., \& Roscigno, V. J. (2016). Power, Status , and Abuse at Work: General and Sexual Harassment Compared Published by: Wiley on behalf of the Midwest Sociological Society Stable URL: http://wnw.jstor.org/stable/40220119 POWER, STATUS , AND ABUSE AT WORK: General and Sexual Harass. 50(1), 3-27.

Lovell, J., \& Jacoby, S. M. (1987). Employing Bureaucracy: Managers, Unions and the Transformation of Work in American Industry, 1900-1945. The Economic History Review. https://doi.org/10.2307/2596334

M. Reena, D. O. S. (2014). Sexual Harassment against Women at Educational Institutions. International Journal of Science and Research (IJSR).

Mask, S. L. (1997). Sexual Harassment in the Ivory Tower-Revisited. Contemporary Psychology: A Journal of Reviews. https://doi.org/10.1037/000177

McLaughlin, H., Uggen, C., \& Blackstone, A. (2012). Sexual Harassment, Workplace Authority, and the Paradox of Power. American Sociological Review, 77(4), 625-647. https://doi.org/10.1177/0003122412451728

Mohd Nazari Ismail, L. K. C. and C. F. B. (2007). Factors Influencing Sexual Harassment in The Malaysian Workplace. Asian Academy of Management Journal, 12(2), 15-31. http://www.researchgate.net/publication /43655784_FACTORS_INFLUENCING_SEXUAL_HARASSMENT_IN_THE_MALAYSIAN_W ORKPLACE

Pryor, J. B., Giedd, J. L., \& Williams, K. B. (1995). A Social Psychological Model for Predicting Sexual Harassment. Journal of Social Issues. https://doi.org/10.1111/j.1540-4560.1995.tb01309.x

Settles, I. H., Buchanan, N. C. T., Yap, S. C. Y., \& Harrell, Z. A. T. (2014). Sex differences in outcomes and harasser characteristics associated with frightening sexual harassment appraisals. Journal of Occupational Health Psychology. https://doi.org/10.1037/a0035449

Sheffey, S., \& TINDALE, R. S. (1992). Perceptions of Sexual Harassment in the Workplace. Journal of Applied Social Psychology. https://doi.org/10.1111/j.1559-1816.1992.tb00963.x

Stockdale, M. S., \& Vaux, A. (1993). What sexual harassment experiences lead respondents to acknowledge being sexually harassed? A secondary analysis of a University Survey. Journal of Vocational Behavior. https://doi.org/10.1006/jvbe.1993.1044

Stockdale, M. S., Vaux, A., \& Cashin, J. (1995). Acknowledging Sexual Harassment: A Test of Alternative Models. Basic and Applied Social Psychology. https://doi.org/10.1207/s15324834basp1704_4

Strachan, G., Adikaram, A., \& Kailasapathy, P. (2015). Gender (In)equality in South Asia: Problems, prospects and pathways. In South Asian Journal of Human Resources Management. https://doi.org/10.1177/2322093715580222

T., S. (2020). A Review of Coronavirus Disease-2019 (COVID-19). Indian Journal of Pediatrics.

Wasti, S. A., Bergman, M. E., Glomb, T. M., \& Drasgow, F. (2000). Test of the cross-cultural generalizability of a model of sexual harassment. Journal of Applied Psychology. https://doi.org/10.1037/00219010.85.5.766

WHO. (2008). Advocacy, communication and social mobilization for TB control. A guide to developing knowledge, attitude and practice surveys. In World Health Organisation.

Wilson, F., \& Thompson, P. (2001). Sexual harassment as an exercise of power. Gender, Work and Organization. https://doi.org/10.1111/1468-0432.00122 